\title{
The Strict Liability of Polluting Corporations Caused Land Fires That Pose a Serious Threat to the Environment
}

\author{
Rony Andre Christian Naldo ${ }^{1}$, Bismar Nasution ${ }^{2}$, Alvi Syahrin ${ }^{3}$, Ningrum Natasya Sirait ${ }^{4}$ \\ \{ronyandre87@gmail.com ${ }^{1}$, bismarnasution@gmail.com ${ }^{2}$, alviprofdr@gmail.com ${ }^{3}$ \} \\ ${ }^{1}$ Universitas Sumatera Utara, Jl. Abdul Hakim No.1. Medan, Indonesia \\ ${ }^{2,3,4}$ Universitas Sumatera Utara, Jl. Abdul Hakim No.1. Medan, Indonesia
}

\begin{abstract}
Every corporation is obliged to maintain the sustainability of environmental functions. The fact that is on the island of Sumatera, there are various corporations whose land is burned. This paper will discuss on strict liability of polluting corporations resulting from land fires that pose a serious threat to the environment. Furthermore, it describes constraints and solutions in applying strict liability to corporation pollution due to land fires which poses a serious threat to the enviroment. This research is a normative legal research which used normative juridical holistic approach method in order to analyze various laws and regulations related to the strict liability of polluting corporations from land fires that pose a serious threat to the environment. As conclusion, there are four obstacles and six solutions in applying strict liability to corporation pollution due to land fires that pose a serious threat to the environment.
\end{abstract}

Keywords: Strict Liability, Corporations, Environment.

\section{Introduction}

Business is an activity done by people on a regular and ongoing basis, with the ultimate arm is to earn a profit. One of the business activities undertaken by corporations in Indonesia, which closely related to the environment is the business of oil palm plantations. As a legal subject, in conducting business activities, based on the provision of Article 68 Sub-Article b of Law Number 32 Year 2009 regarding Environmental Protection and Management (Law Number 32 Year 2009), every corporation have an obligation to maintan the suistainability of environmental functions, which is done by preventing the occurrence of pollution that goes beyond the standard criteria of environmental damage, which a poses a serious threat to the environmental. Fires of corporations can cause pollution that goes beyond the standard criteria of environmental damage, posing a serious threat to the environment. With the occurrence of pollution that exceeds the standard criteria of environmental damage due to land fires that pose a serious threat to the environment, based on the provision of Article 56 verse (1) of Law Number 39 Year 2014 regarding Plantation (Law Number 39 Year 2014) every corporation is prohibited to open and/or cultivate land by burning. Facts on the island of Sumatera, there are various corporations whose land are burned. With the occurrence of pollution due to land fires that go beyond the standard criteria of environmental damage there by posing a serious threat 
to the environment, based on the provision of Article 88 Law Number 32 Year 2009 is tort, which results in strict liability of polluting corporations to pay compensation for losses incurred without the need to prove the element of fault.

\section{Formulation of problems}

The problem in this research is how constraints and solutions in applying strict liability to corporation pollution due to land fires which poses a serious threat to the enviroment?

\section{Literature Review}

The law controls justice, where justice must fulfill the values equality before the law, human rights, truth, obedience, and protecting society [1]. Indonesia is a state law that recognizes and protects the human rights of all Indonesian citizen. The protection of human rights is one of the main principles that become the main pillars of state law support. The protection of human rights provided by the government is a manifestation of legal protection for all Indonesian citizen. Based on Fitzgerald's Legal Protection Theory, legal protection for the interests of a party may be granted by limiting interests on the other. The interest of the law are none other than to take care of human rights and interest in accordance with the provisions of law which have been determined in various laws and regulations. The protection of the law should be able to protect the human rights of the disadvantaged society, and be given so that the community can enjoy all the rights that have been accommodated by the law [2]. Based on the provision of Article $28 \mathrm{H}$ verse (1) of 1945 Constitution of the Indonesian Republic, and Article 9 verse (3) of Law Number 39 Year 1999 regarding Human Rights (Law Number 39 Year 1999), a good and healthy environment is a constitutional and human rights right for all Indonesian citizen. To provide legal protection, the government must make efforts to enforce the law. Law enforcement is an adjustment of the relationships of various values that have been described in various rules, a steady and applied view in the attitude of action as a sequence of the final value stages of expression to create peace in the social life [3]. Efforts to achieve law enforcement, one of which can be done by filing a lawsuit act against the law, to demand payment of compensation as a form a liability for the corporation law of polluters.

\section{Research Methods}

This study used a type of normative legal research [4]. The method used is the juridical normative holistic method [5]. This study is descriptive analysis. The data of this research are usually normative law research, that is using secondary data either in the form of primary, secondary, and tertiary legal material as main data/research subject [6]. All the data already obtained and collected will then be reviewed and analyzed qualitatively. 


\section{Results and Discussions}

Against any polluter corporation on the island of Sumatera, the government through the Ministry of Environment and Forestry (MEF), has made efforts to enforce the law by filing a lawsuit act against the law to seek payment of compensation as a form of legal liability. The facts regarding law enforcement process through filling lawsuits act against the law by the MEF to request compensation payments as a form of liability for corporation law of polluters can be seen in Table 1 .

Table 1. The Law Enforcement Process Through The Filing of a Lawsuit Act Against The Law by The Ministry of Environment and Forestry to Request Payment of Compensation As a Form of Liability of The Corporation Law of Polluters.

\begin{tabular}{|c|c|c|c|c|}
\hline NO & CORPORATION & DISTRICT COURT & HIGH COURT & $\begin{array}{l}\text { SUPREME } \\
\text { COURT }\end{array}$ \\
\hline 1 & PT. KA & $\begin{array}{l}\text { The Meulaboh District } \\
\text { Court Granting the } \\
\text { Entire Compensation } \\
\text { Suit Filed by the MEF. } \\
\text { PT. KA Punished to Pay } \\
\text { Compensation Amount } \\
\text { Rp. } 366.000 .000 .000 \text {. }\end{array}$ & $\begin{array}{l}\text { The Aceh High Court } \\
\text { Rejecting An Appeal } \\
\text { Lawsuit Filed by PT. } \\
\text { KA. }\end{array}$ & $\begin{array}{l}\text { The Supreme } \\
\text { Court Rejected } \\
\text { the Cassation } \\
\text { Appeal Filed by } \\
\text { PT. KA. }\end{array}$ \\
\hline 2 & PT. SPS II & $\begin{array}{l}\text { The South Jakarta } \\
\text { District Court Granted a } \\
\text { Compensation Suit } \\
\text { Filed by the MEF. PT. } \\
\text { SPS II Punished to Pay } \\
\text { Compensation Amount } \\
\text { Rp. 439.000.000.000. }\end{array}$ & $\begin{array}{l}\text { The Jakarta High Court } \\
\text { Overturned the South } \\
\text { Jakarta District Court } \\
\text { Rulling. }\end{array}$ & $\begin{array}{l}\text { The Supreme } \\
\text { Court Rejected } \\
\text { the Cassation } \\
\text { Appeal Filed by } \\
\text { the MEF. }\end{array}$ \\
\hline 3 & PT. NSP & $\begin{array}{l}\text { The South Jakarta } \\
\text { District Court Granted } \\
\text { the Compensation } \\
\text { Claim Filed by the } \\
\text { MEF. PT. NSP was } \\
\text { Punished to Pay } \\
\text { Compensation and } \\
\text { Environmental } \\
\text { Restoration Measures of } \\
\text { Rp. 1.007.000.000.000, } \\
\text { and is Required to Pay a } \\
\text { Court Fee of Rp. } \\
\text { 462.000. Also Required } \\
\text { to Pay for Forced } \\
\text { Money Rp. 50.000.000 } \\
\text { Every Day for the } \\
\text { Delay. }\end{array}$ & & \\
\hline 4 & PT. RKK & $\begin{array}{l}\text { The Jambi District } \\
\text { Court Rejected the } \\
\text { Proposed Compensation } \\
\text { Claim by the MEF. } \\
\text { Requires the MEF to } \\
\text { Pay the Cost of the Case } \\
\text { Amounting to Rp. }\end{array}$ & $\begin{array}{l}\text { The Jambi High Court } \\
\text { Punish PT. RKK to Pay } \\
\text { Material Compensation } \\
\text { of Rp. 44.700.000.000, } \\
\text { and Pay Compensation } \\
\text { for the Cost of } \\
\text { Restoration }\end{array}$ & \\
\hline
\end{tabular}




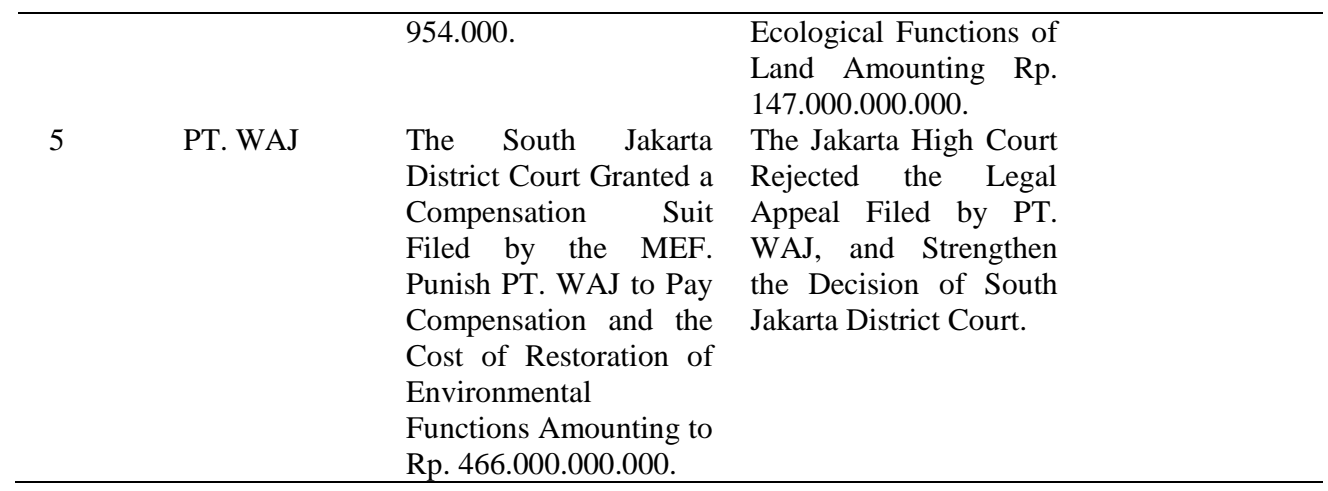

There are various obstacles in applying strict liability to corporation pollution due to land fires that pose a serious threat to the environment. First, the District Court didn't immediately execute a verdict that has permanent and definite legal force. Second, in the case of a verdict which has a permanent and definite legal force, the polluting corporation takes the fight to delay or eliminate the obligation to pay compensation. Third, the district court granted a corollary polluting corporation, which automatically annulled decisions that has permanent and definite legal force. Fourth, not all judges of the judiciary have adhered to the provisions of Article 88 and various principles of Law Number 32 Year 2009 which has been adopted of 1992 Rio De Janeiro Declaration, and doctrine in dubio pro natura.

There are various solutions in applying strict liability to corporation pollution due to land fires that pose a serious threat to the environment. First, the District Court immediately executes the polluting corporation against a decision which has permanent and definite legal force. Second, in the verdict, the judges applies a judgment which may be carried out in advance even if there is a remedy. Third, in the verdict the judge imposed the payment of forced money against the polluting corporation upon each day of the late payment of compensation, as mandated by the Article 87 verse (3) of Law Number 32 Year 2009. Fourth, in the case of environmental pollution, the judge must become a mouthpiece of the law, by holding firmly to Article 88 and various principles of Law Number 32 Year 2009, and doctrine in dubio pro natura. Fifth, the government with the legislature immediately revised Article 2 of Law Number 32 Year 2009, by incorporating the doctrine in dubio pro natura as one of the principles. Sixth, the government with the legislature immediately revised in order to harmonize Law Number 25 Year 2007 regarding Capital Investment, Law Number 40 Year 2007 regarding Limited Liability Companies, Law Number 32 Year 2009, Law Number 39 Year 2014, Law Number 40 Year 2014 regarding Insurance Business, by requiring the corporation to insure it's business activities, so that if it's punished to pay compensation for a land fires that causes pollution, the corporation isn't constrained financially to pay to the state treasury.

\section{Conclusion}

The strict liability to corporation pollution caused by land fires that poses a serious threat to the environment hasn't been applied by all judges to the judiciary. There are four obstacles and six solutions in applying strict liability to corporation pollution due to land fires that pose a serious threat to the environment. 


\section{References}

[1] Harahap, M. Yahya.: Beberapa Tinjauan Tentang Permasalahan Hukum. Citra Aditya Bakti, Bandung. pp. 54 (1997)

[2] Rahardjo, Satjipto.: Ilmu Hukum, Citra Aditya Bankti, Bandung. pp. 54-55 (2006)

[3] Soekanto, Soerjono.: Beberapa Permasalahan Hukum Dalam Kerangka Pembangunan di Indonesia. Universitas Indonesia Press, Jakarta. pp. 3 (1983)

[4] Soemitro, Ronny Hanitijo.: Metodologi Penelitian Hukum dan Jurimetri. Ghalia Indonesia, Jakarta. pp. 10 (1988)

[5] Nasution, Bismar.: Metode Penelitian Hukum Normatif dan Perbandingan Hukum. Universitas Sumatera Utara, Medan. pp. 1 (2016)

[6] Soerjono, Soekanto.: Pengantar Penelitian Hukum. Universitas Indonesia Press, Jakarta. pp. 51 (1986) 